\title{
sciendo \\ APPLICATION OF STEAM JET INJECTOR FOR LATENT HEAT RECOVERY OF MARINE STEAM TURBINE PROPULSION PLANT
}

DOI 10.2478/ntpe-2018-0030

\author{
MSc. Szymon Grzesiak \\ Marine Engineer Class II, \\ working on LNG carriers \\ in world trade shipping \\ Assoc. Prof. PhD. Andrzej Adamkiewicz \\ Maritime University of Szczecin, Poland
}

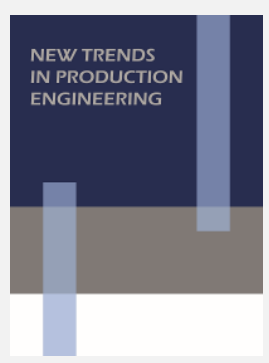

2018

Volume 1

Issue 1

pp. $235-244$

\begin{abstract}
This paper presents the results of previously carried out analyses regarding efficiency and criteria evaluation of various propulsion plants of modern LNG (Liquid Natural Gas) carriers. The results of previous identification and quality assessment of waste heat energy sources of a CST (Conventional Steam Turbine) plant are presente. In this paper the possibility of use a steam jet injector in order to recover the latent heat is analysed. Calculations were carried out for an injector equipped with a de Laval nozzle, determining the thermodynamic state parameters of the mixture of drive steam and sucked in steam as well as the steam on the outlet of the injector for the various ejection ratios. On the basis of the results of the injector calculation, the heat balance of a simple regenerative Clausius - Rankine steam cycle (with one regenerative heater - deaerator) was carried out. The degree of regeneration (increase of the thermal efficiency) for cycle using the regenerative injector was determined. Based on results the further research directions for complex plants using a steam jets are indicated.
\end{abstract}

Keywords: thermal efficiency, propulsion plant, steam turbine, steam jet injector

\section{INTRODUCTION}

The carried out analysis of the steam turbine plants of modern LNG carriers (Adamkiewicz A. and Grzesiak S. 2016, Behrendt C. and Adamkiewicz A. 2010), indicates that their thermal efficiency is not sufficient. Too low efficiency of these systems also adversely affects their criterion evaluation in terms of ecological as well as economic criteria. Despite advantages such as reliability, low maintenance and operational costs (OPEX - OPerational EXpenditure), low emission of toxic gases and harmful compounds $\left(N O_{x}, S_{x}, H C\right)$ or ease of energy conversion, are driven out of the market by highly efficient plants equipped with marine diesel engines (IGU World LNG Report 2018). Table 1 presents the results of criterion evaluation of CST and reheat steam plants (ART - Advance Reheat Turbine; UST - Ultra Steam Turbine) and alternative systems such as DFDE/TFDE (Dual/Triple Fuel Diesel Electric), DRL (Diesel with Reliquification), CoGAS (Combined Gas And Steam Turbine) and DF SSD (Dual Fuel Slow Speed Diesel) (Patel M., Nath N 2000).

In order to analyse the possibility of increasing the efficiency of steam turbine plant, the identification of waste heat sources and quality assessment of two main waste heat streams (exhaust gas streams from main boilers and losses in condenser - latent heat streams) were carried out (Adamkiewicz A., Grzesiak S. 2018). 
Table 1.

Statement of main criteria of presented propulsion plants.

\begin{tabular}{|c|c|c|c|c|c|}
\hline & $\begin{array}{l}\text { Environmental } \\
\text { Compliance }\end{array}$ & $\begin{array}{l}\text { Thermal } \\
\text { Efficiency }\end{array}$ & Fuel System & Reliability & OPEX \\
\hline $\begin{array}{l}\text { Steam } \\
\text { Plant }\end{array}$ & $\begin{array}{l}\text { 1. Meets Tier III (gas mode) } \\
\text { 2. SCR required. for TIER III } \\
\text { (FO mode) } \\
\text { 3. High } \mathrm{CO}_{2} \text { emission }\end{array}$ & $\begin{array}{l}\eta_{C S T}=0.30 \\
\eta_{\text {reheat }}=0.41\end{array}$ & $\begin{array}{l}3 \text { fuel modes: } \\
\text { Gas only } \\
\text { Dual fuel } \\
\text { (any ratio) } \\
\text { FO only }\end{array}$ & $\begin{array}{l}\text { High } \\
\text { Low } \\
\text { redundancy }\end{array}$ & $\begin{array}{l}\text { Low } \\
\text { High Fuel } \\
\text { costs }\end{array}$ \\
\hline $\begin{array}{l}\text { DFDE/ } \\
\text { TFDE }\end{array}$ & $\begin{array}{l}\text { 1. Meets Tier III (gas mode) } \\
\text { 2. SCR for TIER III (FO } \\
\text { mode) }\end{array}$ & $\eta_{D E}=0.42$ & $\begin{array}{l}2 \text { modes: } \\
\text { Fuel only } \\
\text { Gas mode (min } \\
\text { load } 10 \%+1 \% \\
\text { pilot fuel) }\end{array}$ & $\begin{array}{l}<\text { Steam plant } \\
\text { High } \\
\text { redundancy }\end{array}$ & $\begin{array}{l}\text { High Engine } \\
\text { maintenance } \\
\text { costs }\end{array}$ \\
\hline DRL & $\begin{array}{l}\text { 1. EGR or SCR for TIER III } \\
\text { (FO mode) } \\
\text { 2. Scrubber or LS Fuel for } \\
\text { SECA regions }\end{array}$ & $\eta_{D R L}=0.47$ & $\begin{array}{l}\text { No gas burning } \\
\text { (min load } 10 \%+3- \\
5 \% \text { pilot fuel) }\end{array}$ & $\begin{array}{l}<\text { Steam plant } \\
\text { propulsion } \\
\text { redundancy }\end{array}$ & $\begin{array}{l}\text { High Engine } \\
\text { maintenance } \\
\text { costs }\end{array}$ \\
\hline DF SSD & $\begin{array}{l}\text { 1. EGR required for TIER III } \\
\text { 2. Low } \mathrm{CO} 2 \text { emission }\end{array}$ & $\eta_{M E G I}=0.51$ & $\begin{array}{l}\text { FO } \\
\text { only(MDO/HFO) } \\
\text { Gas shear mode }\end{array}$ & $\begin{array}{l}\text { Unknown } \\
\text { propulsion } \\
\text { redundancy }\end{array}$ & $\begin{array}{l}\text { High Engine } \\
\text { and } \\
\text { compressors } \\
\text { maintenance } \\
\text { costs }\end{array}$ \\
\hline COGAS & $\begin{array}{l}\text { Meets TIER III (gas mode or } \\
\text { MDO) }\end{array}$ & $\eta_{C}=0.41$ & $\begin{array}{l}\text { FO only (MDO) } \\
\text { Gas burning } \\
\text { (3-5\% pilot fuel) }\end{array}$ & $\begin{array}{l}\text { Not proven for } \\
\text { LNG carriers }\end{array}$ & $\begin{array}{l}<\text { DFDE } \\
>\text { Steam plant }\end{array}$ \\
\hline
\end{tabular}

Source: (Grzesiak S. 2018)

Table 2 and 3 present, respectively, the results of the heat balance and the quality assessment of the main waste energy sources for CST plant.

Table 2.

Heat balance for CST plant at $100 \%$ MCR.

\begin{tabular}{|c|c|c|c|c|c|c|c|c|c|}
\hline \multicolumn{10}{|c|}{ HEAT BALANCE FOR PLANT AT 100\% MCR (29080 kW @ shaft speed 90 RPM) } \\
\hline & \multirow[t]{2}{*}{ Medium } & \multirow{2}{*}{$\begin{array}{l}\text { Flow } \\
\mathrm{kg} / \mathrm{h} \\
\end{array}$} & \multirow{2}{*}{$\begin{array}{c}\text { Press. } \\
\text { bar }\end{array}$} & \multirow{2}{*}{$\begin{array}{c}\text { Temp. } \\
{ }^{\circ} \mathrm{C}\end{array}$} & \multirow{2}{*}{$\begin{array}{c}\text { Enthalpy } \\
\text { kJ/kg }\end{array}$} & \multicolumn{2}{|c|}{ Energy Flux } & \multirow{2}{*}{$\begin{array}{c}\begin{array}{c}\text { Specific } \\
\text { heat }\end{array} \\
\mathrm{kJ} / \mathrm{kWh}\end{array}$} & \multirow{2}{*}{$\begin{array}{c}\text { Percen. } \\
\%\end{array}$} \\
\hline & & & & & & $k J / h$ & kW & & \\
\hline MT useful energy & $\begin{array}{l}\text { Mechanical } \\
\text { energy }\end{array}$ & $x x x$ & $\mathrm{xxx}$ & $x \mathrm{xx}$ & $x \mathrm{xx}$ & 104688000 & 29080 & 3600.00 & 29.2 \\
\hline TA useful energy & $\begin{array}{l}\text { Electrical } \\
\text { energy }\end{array}$ & $x \mathrm{xx}$ & $x \mathrm{xx}$ & $x \mathrm{xx}$ & $x \mathrm{xx}$ & 5310000 & 1475 & 182.60 & 1.5 \\
\hline $\begin{array}{l}\text { Aux Steam useful } \\
\text { energy }\end{array}$ & $\begin{array}{l}\text { Heat energy - } \\
\text { Steam }\end{array}$ & 2572 & 9 & 175 & 2773 & 6468314 & 1796.8 & 222.43 & 1.8 \\
\hline MT condenser losses & $\begin{array}{l}\text { Heat energy - } \\
\text { Steam }\end{array}$ & 81388.62 & 0.066 & 38 & 2294 & 175473867 & $\begin{array}{c}48742 . \\
7\end{array}$ & 6034.18 & 49 \\
\hline TA condenser losses & $\begin{array}{l}\text { Heat energy - } \\
\text { Steam }\end{array}$ & 5715.809 & 0.075 & 40 & 2452 & 13226381 & 3674 & 454.83 & 3.7 \\
\hline Exhaust losses & $\begin{array}{l}\text { Heat energy } \\
\text { Exhaust gases }\end{array}$ & 157827.5 & $\stackrel{>}{\text { Atmos. }}$ & 155 & 285 & 44935857 & 351.1 & 43.46 & 12.5 \\
\hline MT mechanical losses & Friction/Heat & $x x x$ & $x x x$ & $x x x$ & $x x x$ & 2851577 & 792.1 & 98.06 & 0.8 \\
\hline TA mechanical losses & Friction/Heat & $x x x$ & $x x x$ & $x x x$ & $x x x$ & 174560 & 48.5 & 6.00 & 0.05 \\
\hline FP mechanical losses & Friction/Heat & $x x x$ & $x x x$ & $x x x$ & $x x x$ & 44243 & 12.29 & 1.52 & 0.01 \\
\hline MT gearbox losses & Friction/Heat & $x x x$ & $x x x$ & $\mathrm{xxx}$ & $x x x$ & 2136489.8 & 593.5 & 73.47 & 0.6 \\
\hline TA gearbox losses & Friction/Heat & $x x x$ & $x x x$ & $x x x$ & $x x x$ & 112882.6 & 31.4 & 3.88 & 0.03 \\
\hline Flow losses in pipe lines & $\begin{array}{l}\text { Heat/Flow } \\
\text { restriction }\end{array}$ & $x x x$ & $x \mathrm{xx}$ & $x x x$ & $x x x$ & 1263915.3 & 351.1 & 43.46 & 0.4 \\
\hline FP Pump losses & & $x x x$ & $x x x$ & $x x x$ & $x x x$ & 572208.9 & 158.9 & 19.68 & 0.16 \\
\hline TA Alternator losses & $\begin{array}{l}\text { Resistance/He } \\
\text { at }\end{array}$ & $x \mathrm{xx}$ & $x \mathrm{xx}$ & $x \mathrm{xx}$ & $x x x$ & 221250 & 61.5 & 7.61 & 0.06 \\
\hline SUB TOTAL & & & & & & 357479548 & 87168 & 10791.1 & 99.81 \\
\hline
\end{tabular}

Source: (Adamkiewicz A., Grzesiak S. 2018)

The determined energy quality indicators: the temperature one $\psi=f(T)$ and the exergy one $\psi=f(b, i)$ for exhaust gases point out to a high potential of this source. There are both a high temperature difference $\left(t_{\text {exh }}=155^{\circ} \mathrm{C} ; t_{0}=30^{\circ} \mathrm{C}\right.$ ) as well as a considerable energy flux (about $12.5 \%$ of the energy introduced into the system). Usability of energy contained in the exhaust gases is limited by the maximum cooling temperature of exhaust on outlet of economizer with regards to the acid dew point. 
Table 3.

Determined functions of evaluation of the waste energy source quality.

\begin{tabular}{|l|c|c|c|c|c|c|c|c|c|}
\hline & Flow & Energy flux & $\begin{array}{c}\text { Press. } \\
\text { Abs. }\end{array}$ & Temp & Enthalpy & $\mathbf{x}$ & Exergy & $\boldsymbol{\Psi}$ temp & $\boldsymbol{\Psi} \mathbf{f ( b , i )}$ \\
\cline { 2 - 11 } & $\mathbf{k g} / \mathbf{h}$ & $\mathbf{k J / h}$ & $\mathbf{b a r}$ & ${ }^{\circ} \mathbf{C}$ & $\mathbf{k J} / \mathbf{k g}$ & - & $\mathbf{k J} / \mathbf{k g}$ & - & - \\
\hline $\begin{array}{l}\text { MT condenser } \\
\text { losses }\end{array}$ & 81388.62 & 175473867.3 & 0.066 & 38 & 2294 & 0.888 & 1926.44 & 0.132 & 0.8936 \\
\hline $\begin{array}{l}\text { TA condenser } \\
\text { losses }\end{array}$ & 5715.81 & 13226381.8 & 0.075 & 40 & 2452 & 0.95 & 2069.74 & 0.175 & 0.8945 \\
\hline Exhaust losses & 157827.5 & 44935857.3 & 1.05 & 155 & 285 & $\mathrm{xxx}$ & 139.251 & 0.806 & 0.5461 \\
\hline
\end{tabular}

Source: (Adamkiewicz A., Grzesiak S. 2018)

The determined values of physical exergy ( $\left.b_{\text {steam}}\right)$ as well as the exergy coefficient of energy quality $(\psi=f(b, i))$ for the exhaust steam from the main turbine as well as from the turbo generator unit point to a very high energy potential of these fluxes. However, due to low energy state, a small temperature difference and high dispersion of the exhaust steam heat, direct use of this heat in a classical ship heat exchanger (with partitions between the heating medium and a medium receiving the heat) is not possible. In conclusion of paper (Adamkiewicz A. Grzesiak S. 2018), it is pointed that the obtained and presented results are technical hints indicating rational utilization of the identified waste heat from the process of mixing fluxes. In paragraph 2 model of the cycle using the regenerative injector for recovery of latent heat wasted in main condenser is presented.

\section{MODEL OF THE STUDIED STEAM CYCLE}

Figure 1 presents a thermal - flow diagram of the system working according to ClausiusRankine cycle with one stage of regenerative heating (deaerator) (variant $A$ ) and the system that is modified by addition of regeneration injector (variant B).

a)

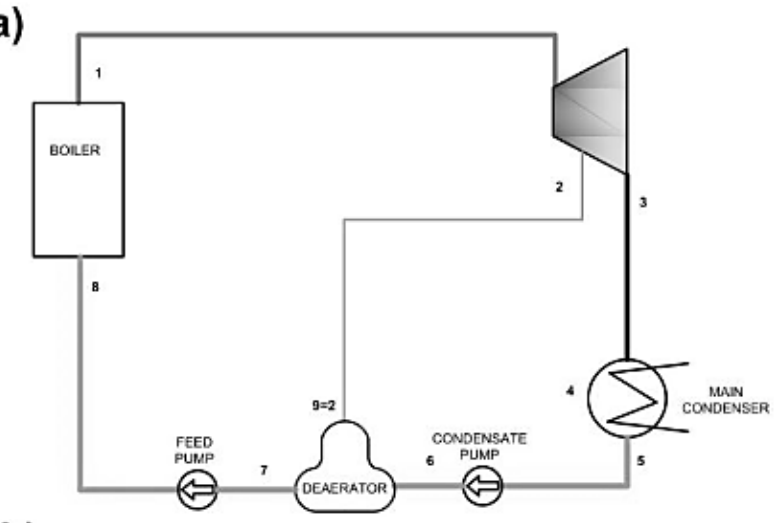

b)

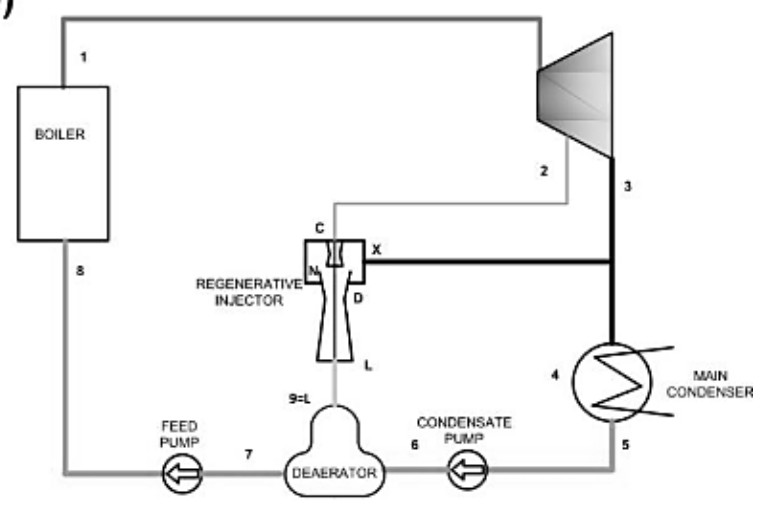

Fig. 1. Thermal - Flow Diagram of proposed model:

a) Clausius-Rankine cycle with regenerative heater (deaerator) feed from steam bleed;

b) Clausius-Rankine cycle with regenerative heater (deaerator) feed by regenerative injector 
Presented cycles consist of a steam boiler producing superheated steam with the parameters of point $1\left(p_{1}, t_{1}, i_{1}\right)$, steam turbine, vacuum main condenser, condensate pump, regenerative heater (deaerator) and feed pump. The regenerative heater of variant $A$ is supplied by a bleed steam from the turbine. In the variant $B$, the heater is supplied with a mixture of bleed and exhaust steam from the turbine. Mixing of these two streams takes place in the mixing chamber of the regenerative injector. For the purpose of analysing the proposed solution, heat balance of the cycle was carried out, for which it was necessary to perform calculations of the injector, determining the parameters of the outlet mixture and the required parameters of drive steam for injector.

\section{Calculation of state parameters of injector}

Figure 2 shows a steam injector whose task is to increase the energy potential of exhaust steam from a steam turbine to efficiently use latent heat.

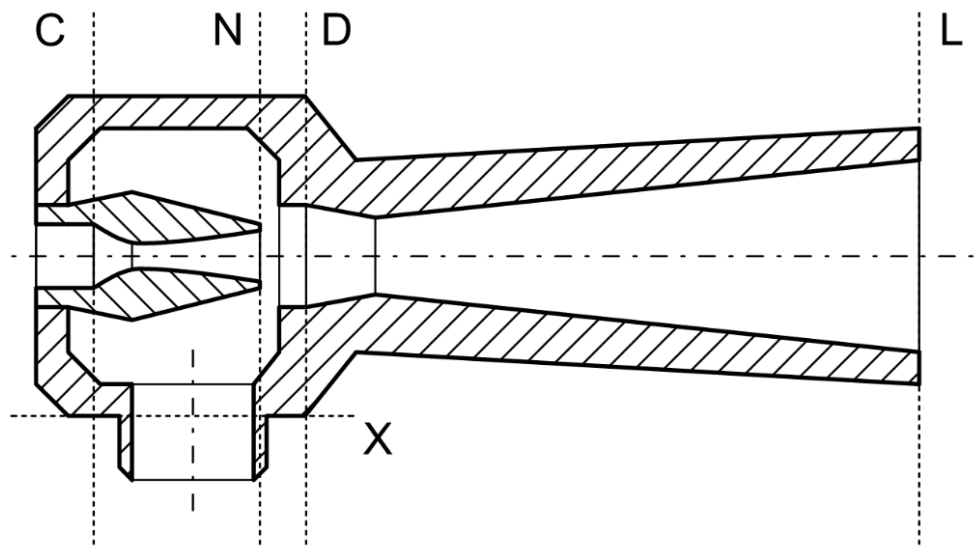

Fig. 2. Cross section of calculated injector with de Laval nozzle.

Injector consists of:

- convergent-divergent nozzle de Laval (C-N), due to exceeding the parameters critical in a nozzle with a convergent channel;

- mixing chamber (N-D) in which the streams are expanded in the nozzle steam and steam sucked in, where energy is also exchanged between streams and partial drying of the mixture as a result of losses of kinetic energy;

- Diffuser $(<L)$, in which the kinetic energy is changed into heat and potential energy of the static pressure of mixture.

The calculations were made in accordance with the algorithm shown in Figure 3.

In the first step, it is necessary to assume the value of losses occurring in the individual construction elements of the injector. The values of these coefficients, presented in Table 4, were assumed based on the literature (Bukurov M. and Bikic S. and Prica M 2012; Goliński A. and Troskolański T.1979; Drożyński Z., and Konorski A.1980; Gryboś R. 1956; Hegazy A. 2007; Trela M. and Kwidzinski R. and Gluch J. 2009). 


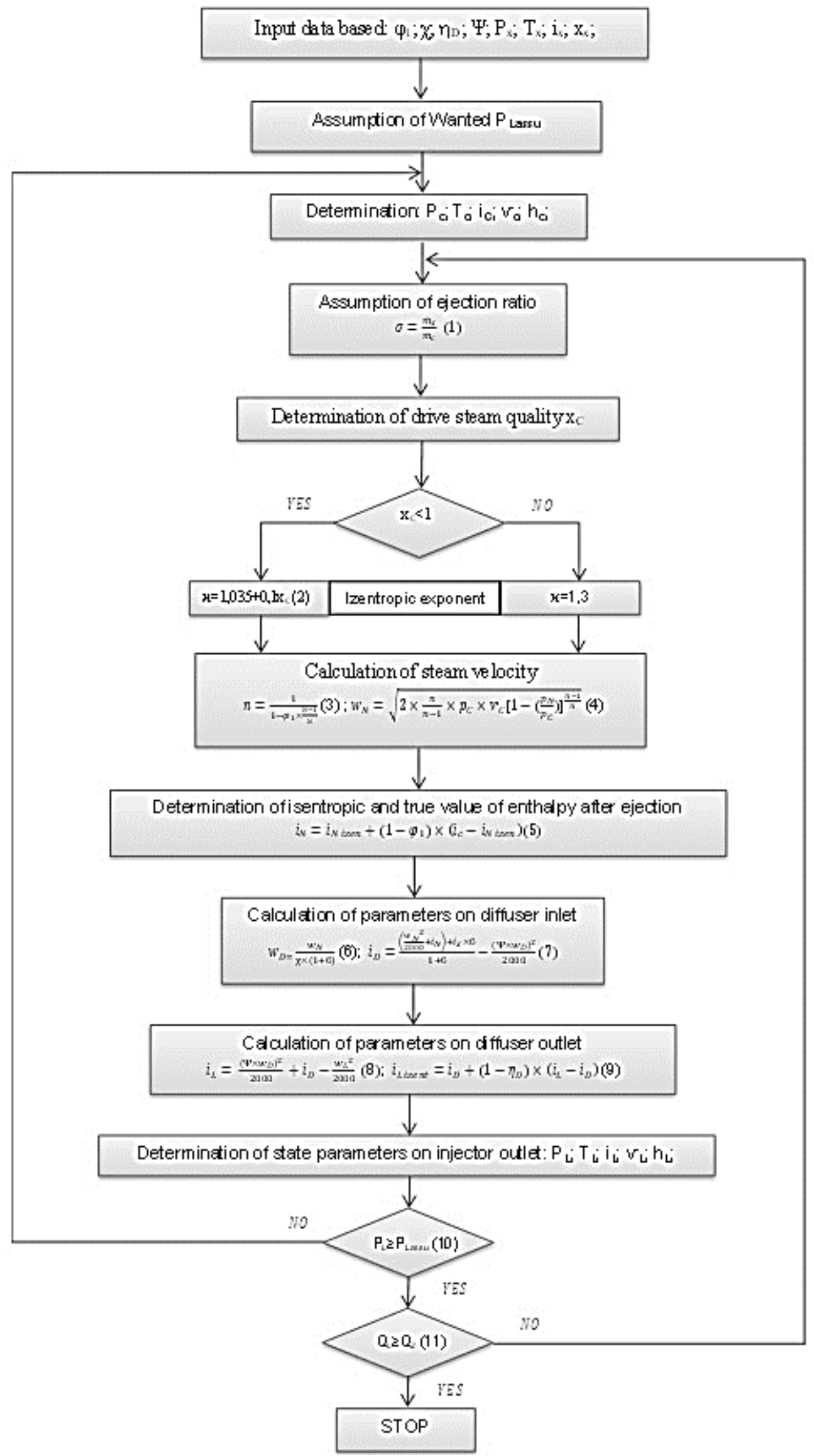

Fig. 3. Algorithm of regenerative injector calculation. 
Table 4.

Determined coefficient of injector losses.

\begin{tabular}{|c|l|r|l|}
\hline$\varphi_{1}$ & Coefficient of loss of the nozzle. & 0.9 & Goliński \\
\hline$X$ & Coefficient of velocity unevenness profile. & 0.943 & $\begin{array}{l}\text { Drożyński } \\
\text { Gryboś }\end{array}$ \\
\hline$\Psi$ & $\begin{array}{l}\text { Coefficient for averaging of the velocity relative to kinetic energy. } \\
\text { Assumed for stabilized velocity profile at a constant pressure of 6600 Pa. }\end{array}$ & 0.9 & $\begin{array}{l}\text { Gryboś } \\
\text { Goliński }\end{array}$ \\
\hline$\eta_{d}$ & Efficiency of the diffuser. & 0.9 & $\begin{array}{l}\text { Gryboś } \\
\text { Hegazy }\end{array}$ \\
\hline
\end{tabular}

In the next stage of calculation, the value of the required pressure after the injector $\mathrm{p}_{\mathrm{L}}-$ was specified, and the state parameters for the drive steam were determined. The calculations were carried out for the assumed ejection ratio in accordance with formula (1) shown on algorithm (Fig. 3). For the determined steam quality $x$, the isentropic exponent (formula 2) and polytrophic exponent (formula 3) were calculated, and then the velocity of the medium after expansion in the nozzle $w_{N}$ (formula 4) and the enthalpy value of $i_{N}$ - (formula 5) were calculated. Enthalpy value for isentropic expansion was read from the i-s diagram (Fig. 3). The velocity and enthalpy of mixture on the inlet to diffuser was determined based on Poisson and Bernoulli equations (formula 6 and 7 ).

Enthalpy of steam mixture on the outlet of injector was determined on the basis of formulas 8 and 9 . The parameters of the state $L$ plane behind the diffuser were determined on the basis of the i-s graph (Fig. 4).

The calculated parameters of individual points are summarized in Table 5.

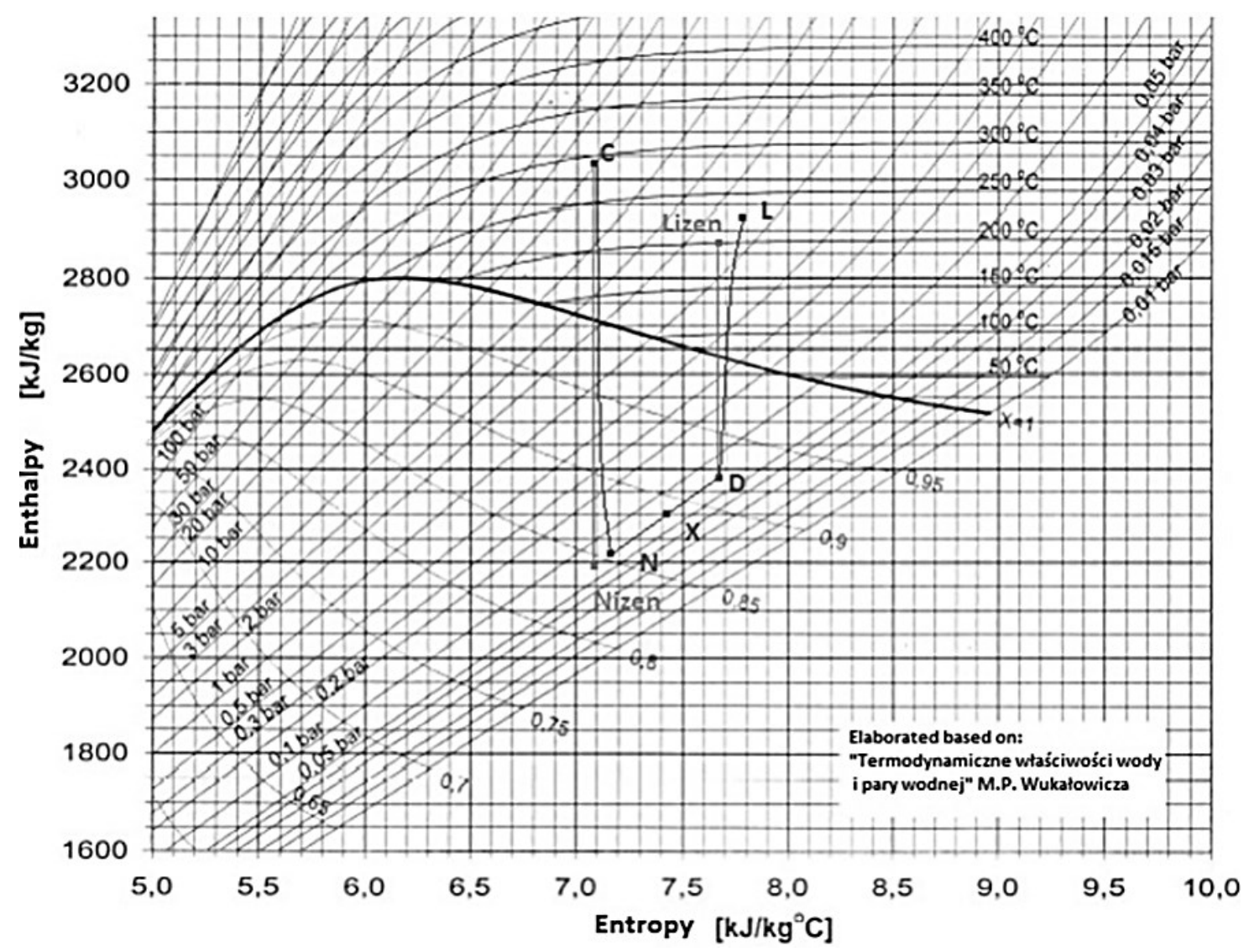

Fig. 4. Expansion and compression in injector shown on i-s diagram for ejection ratio $\sigma=0.143$ 
Table 5.

Determined and calculated parameters by 3 different ejection ratio 6 .

\begin{tabular}{|c|c|c|c|c|c|}
\hline 6 & {$[-]$} & Ejection Ratio - assumed & 0.200 & 0.167 & 0.143 \\
\hline $\mathrm{K}$ & {$[-]$} & Isentropic exponent & 1.3 & 1.3 & 1.3 \\
\hline $\mathrm{N}$ & {$[-]$} & Polytrophic exponent & 1.262 & 1.262 & 1.262 \\
\hline $\mathrm{p}_{\mathrm{c}}$ & {$[\mathrm{Pa}]$} & Pressure of inlet steam & 1000000 & 1000000 & 1000000 \\
\hline$i_{c}$ & {$[\mathrm{~kJ} / \mathrm{kg}]$} & Enthalpy of inlet steam & 3025 & 3025 & 3025 \\
\hline$V_{c}$ & {$\left[\mathrm{~m}^{3} / \mathrm{kg}\right]$} & Specific volume of steam inlet & 0.2518 & 0.2518 & 0.2518 \\
\hline$p_{x}$ & {$[\mathrm{~Pa}]$} & Pressure of steam on suction side & 6600 & 6600 & 6600 \\
\hline $\mathrm{w}_{\mathrm{N}}$ & {$[\mathrm{m} / \mathrm{s}]$} & Velocity of expanded steam & 1253.055 & 1253.055 & 1253.055 \\
\hline $\mathrm{i}_{\text {Nizen }}$ & {$[\mathrm{kJ} / \mathrm{kg}]$} & Enthalpy of steam after isentropic expansion & 2191 & 2191 & 2191 \\
\hline $\mathrm{i}_{\mathrm{N}}$ & {$[\mathrm{kJ} / \mathrm{kg}]$} & Enthalpy of steam after nozzle & 2232.7 & 2232.7 & 2232.7 \\
\hline$W_{D}$ & {$[\mathrm{~m} / \mathrm{s}]$} & Velocity of steam on diffusor inlet & 1107.3 & 1139.0 & 1162.7 \\
\hline is & {$[\mathrm{kJ} / \mathrm{kg}]$} & Enthalpy of steam on diffusor inlet & 2401.5 & 2389.8 & 2380.5 \\
\hline íLizen & {$[\mathrm{kJ} / \mathrm{kg}]$} & $\begin{array}{l}\text { Enthalpy of steam mixture after isentropic } \\
\text { compression }\end{array}$ & 2846.9 & 2861.1 & 2871.7 \\
\hline $\mathrm{i}_{\mathrm{L}}$ & {$[\mathrm{kJ} / \mathrm{kg}]$} & Enthalpy of steam after diffusor & 2896.3 & 2913.4 & 2926.3 \\
\hline$t_{\mathrm{L}}$ & {$\left[{ }^{\circ} \mathrm{C}\right]$} & Temperature of steam after diffusor & 210 & 219 & 226 \\
\hline $\mathrm{pL}$ & {$[\mathrm{Pa}]$} & Pressure of steam after diffusor & 1.05 & 1.22 & 1.39 \\
\hline
\end{tabular}

\section{Heat balances of proposed steam cycle}

For the calculation of the heat balance, the values of steam after the injector for the degree of ejection $\sigma=0.143$ determined in paragraph 2.1 were assumed. The input data to the heat balance for variant $A$ and $B$, and the size of specific mass flow are presented in Table 6 and 7 respectively.

Table 6.

Overview of thermodynamic state parameters in the control planes for variant A.

\begin{tabular}{|c|c|c|c|c|}
\hline \multicolumn{5}{|c|}{ VARIANT A } \\
\hline $\begin{array}{c}\text { Control Plane } \\
\text { from Fig. 1 }\end{array}$ & $\mathbf{p}$ & $\mathbf{t}$ & $\mathbf{i}$ & $\mathbf{~}$ \\
\hline 1 & $\mathbf{P a} \mathbf{A}$ & ${ }^{\circ} \mathbf{C}$ & $\mathbf{k J} / \mathbf{k g}$ & $\mathbf{k g} / \mathbf{s}$ \\
\hline 2 & 59500000 & 520 & 3470 & 1 \\
\hline 3 & 1000000 & 287 & 3025 & 0.104607 \\
\hline 4 & 66000 & 38 & 2300 & 0.895393 \\
\hline 5 & 50000 & 32 & 2990 & 0.895393 \\
\hline 6 & 50000 & 32 & 138 & 0.895393 \\
\hline 7 & 1000000 & 32 & 138 & 0.895393 \\
\hline 8 & 130000 & 105 & 440 & 1 \\
\hline $9=2$ & 7000000 & 105 & 440 & 1 \\
\hline
\end{tabular}

In order to determine the value of specific mass flow in individual control planes for variant $A$, the formula for heat balance (12) of the deaerator was used.

where:

$$
\dot{m}_{2}=\frac{\left(i_{7}-i_{6}\right)}{\left(i_{2}-i_{6}\right)}
$$

$\dot{m}$ - specific mass flow $[\mathrm{kg} / \mathrm{s}]$

$i$ - specific enthalpy in control planes $[\mathrm{kJ} / \mathrm{kg}]$

Values of remaining specific flows were determined based on formula (13).

$$
\dot{m}_{3}=\dot{m}_{4}=\dot{m}_{5}=\dot{m}_{6}=1-\dot{m}_{2}
$$


Table 7.

Overview of thermodynamic state parameters in the control planes for variant B and $6=0.143$

\begin{tabular}{|c|c|c|c|c|}
\hline \multicolumn{5}{|c|}{ VARIANT B for $\sigma=0.143$} \\
\hline \multirow{2}{*}{$\begin{array}{c}\text { Control Plane } \\
\text { from Fig. } 1\end{array}$} & $\mathbf{p}$ & $\mathbf{t}$ & $\mathbf{i}$ & $\mathbf{m}$ \\
\hline & $\mathrm{PaA}$ & ${ }^{\circ} \mathrm{C}$ & $\mathrm{kJ} / \mathrm{kg}$ & $\mathrm{kg} / \mathrm{s}$ \\
\hline 1 & 59500000 & 520 & 3470 & 1 \\
\hline 2 & 1000000 & 287 & 3025 & 0.094781 \\
\hline 3 & 66000 & 38 & 2300 & 0.905218 \\
\hline$x$ & 66000 & 38 & 2300 & 0.013540 \\
\hline 4 & 50000 & 32 & 2990 & 0.891678 \\
\hline 5 & 50000 & 32 & 138 & 0.891678 \\
\hline 6 & 1000000 & 32 & 138 & 0.891678 \\
\hline 7 & 130000 & 105 & 440 & 1 \\
\hline 8 & 7000000 & 105 & 440 & 1 \\
\hline 9 & 139000 & 226 & 2926 & 0.108321 \\
\hline
\end{tabular}

For variant $B$, formulas (14-17) were used to determined specific mass flows in control planes.

$$
\begin{gathered}
\dot{m}_{2}=\frac{\left(i_{7}-i_{6}\right)}{\left(i_{9}-i_{6}\right) \times(1+\sigma)} \\
\dot{m}_{4}=\dot{m}_{5}=\dot{m}_{6}=1-\dot{m}_{2}-\dot{m}_{x} \\
\dot{m}_{3}=1-\dot{m}_{2} \\
\sigma=\frac{\dot{m}_{x}}{\dot{m}_{2}}
\end{gathered}
$$

where:

$\sigma-$ ejection ratio [-]

\section{DISCUSSION}

The thermal efficiency for both variants were determined based on formula (18).

$$
\eta_{t}=\frac{\dot{m}_{1} \times\left(i_{1}-i_{3}\right)-\dot{m}_{2} \times\left(i_{2}-i_{3}\right)}{\left(i_{1}-i_{8}\right)}
$$

The calculated thermal efficiency for variant $\mathrm{A}$ is $\eta_{t A}=0,361109$ and for variant $\mathrm{B} \eta_{t B}=$ 0.363459 . The degree of regeneration $\varepsilon$ was calculated from formula (19).

$$
\varepsilon=\frac{\eta_{t B}-\eta_{t A}}{\eta_{t B}}
$$

where:

$\eta_{t A} ; \eta_{t B}$ - thermal efficiency [-]

The degree of regeneration $\varepsilon$ for assumed ejection ratio equals $\varepsilon_{6=0,143}=0,646845 \%$.

Calculations were carried out again for the ejection ratio $\sigma=0.167$, with decreased of boiler feed water inlet temperature from $t_{8}=105^{\circ} \mathrm{C}$ by $5 \mathrm{~K}$ to $t_{8}=100^{\circ} \mathrm{C}$ due to the need of reduction of deaerator pressure. The achieved thermal efficiency values of variant $A$ and $B$ were respectively: $\eta_{t A}=0.36039$ and $\eta_{t B}=0.362901$. For the higher ejection ratio the higher degree of regeneration was achieved $\varepsilon_{6=0,167}=0.692676 \%$.

Application of a regenerative injector in the deaerator steam supply system results in a decrease of the steam bleed from the turbine, thereby increasing the available specific enthalpy drop across the turbine stages.

By substituting to formula (19), the relations (18) determined for individual variants, we get the equation.

$$
\varepsilon=1-\frac{\dot{m}_{1} \times\left(i_{1}-i_{3}\right)-\dot{m}_{2 A} \times\left(i_{2}-i_{3}\right)}{\dot{m}_{1} \times\left(i_{1}-i_{3}\right)-\dot{m}_{2 B} \times\left(i_{2}-i_{3}\right)}
$$

From the formula 20 it is clear that in order for the degree of regeneration of the system to be above $0(\varepsilon>0)$ the inequality must be met.

$$
\dot{m}_{2 A}>\dot{m}_{2 B}
$$


The values of these specific mass flows can be determined from the conservation equations for mass and energy balances (formula 12, 13 for variant $A$ and 14-17 for variant $B$ ). As a result of that substitution, inequality (22) was obtained.

$$
\frac{\left(i_{7}-i_{6}\right)}{\left(i_{2}-i_{6}\right)}>\frac{\left(i_{7}-i_{6}\right)}{\left(i_{9}-i_{6}\right) \times(1+\sigma)}
$$

Assuming that for an ideal injector the value of specific enthalpy for steam mixture after diffusor can be determined with satisfying accuracy can be determined by formula (23) (Gryboś R. 1956).

$$
i_{9}=\frac{\left(i_{2}+6 \times i_{3}\right)}{(1+6)}
$$

The inequality (21) is correct for every $\sigma>0$.

This simple mathematical proof shows that whenever the steam is passing through the injector and the exhaust steam is sucked in $(\sigma>0)$, there is an increase of the thermal efficiency of the cycle.

\section{CONCLUSSION}

The obtained calculation results show that the application of the steam injector for a simple system results in an increase of the thermal efficiency, if the same parameters of the cycle are maintained. The increase of the thermal efficiency is a result of the reduction of steam bleed from the turbine and thus the increase of the available enthalpy drop across the turbine stages. The analysis shows that increasing of the ejection ration and using the bleed steam from the lowest energy level results in an increase of the cycle thermal efficiency.

Unfortunately, the considered system with regenerative injector to obtain the desired pressure of the steam mixture on the outlet from diffuser requires a relatively high drive steam pressure, thus lowering the available enthalpy drop across turbine. The same temperature of the boiler feed water can be achieved by using the steam from the significantly lower pressure steam bleed resulting in higher available enthalpy drop across turbine stages.

Due to this fact, further researches will be focused on recognising the possibilities of using steam jets injectors in more complex system, using as well vacuum heat exchanger, multi stage compression as well as cooling the drive steam and interstage cooling of mixture. The possibility of optimising operating parameters such as drive steam pressure and ejection rate to obtain the highest regeneration degree of the cycle should be also considered.

\section{REFFERENCE}

Adamkiewicz A., Grzesiak S. (2018): Identification of waste heat energy sources of a conventional steam propulsion plant of an LNG carrier, proceeding of $5^{\text {th }}$ International Conference Bremen, "Low Temperature and Waste Heat Use in Communal and Industrial Energy Supply Systems - Theory and Practice -“

Adamkiewicz A. and Grzesiak S. (2016): Ewolucja efektywności energetycznej turbinowych napędów parowych współczesnych zbiornikowców LNG, Rynek Energii 130/3 p. 92-98

Behrendt C. and Adamkiewicz A. (2010): LNG Carrier Power Systems, RYNEK ENERGI Issue 3 JUN 2010 p. 55-62

Bukurov M. and Bikic S. and Prica M (2012): The Efficiency Rate of a Steam-Water Injector, Acta Polytechnica Hungarica Vol. 9, No. 52012 p. 107-126

Drożyński Z., and Konorski A.(1980): Algorytm wyznaczania parametrów termodynamicznych urządzeń eżektorowych, Instytut Maszyn Przepływowych PAN Gdańsk 2018

Goliński A. and Troskolański T.(1979): Strumienice Teoria i Konstrukcja, Wydawnictwo Naukowo-Techniczne Warszawa 1979

Grzesiak S. (2018): ALTERNATIVE PROPULSION PLANTS FOR MODERN LNG CARRIERS, New Trends in Production Engineering - Volume 1, issue 1, 2018.

Gryboś R. (1956): Regeneracja ciepła w siłowni z turbiną bezupustową, Zeszyty Naukowe Politechniki Śląskiej Issue 1, No 5, Gliwice 1956 p. 59-80

Hegazy A. (2007): Possible Waste Heat Recovery in the Condenser of a Regenerative Steam Cycle, Journal of Thermal Science and Technology Vol 2, No 1, 2007 p. 1-12

Patel M., Nath N (2000).: Improve steam turbine efficiency, Hydrocarbon Processing, Volume: 79 Issue 6 June 2000 p. 85-+ 
IGU World LNG Report (2018) Available at: http://www.igu.org [accessed August 2018]

Trela M. and Kwidzinski R. and Gluch J. (2009): Analysis of application of feed - water injector heaters to steam power plants, Polish Maritime Research Volume 16 Special Issue:1 2009 p. $64-70$

Date of submission of the article to the Editor: 06/2018

Date of acceptance of the article by the Editor: 09/2018 